Article

\title{
Optimal Project Planning for Public Rental Housing in South Korea
}

\author{
Jae Ho Park ${ }^{1}$, Jung-Suk Yu ${ }^{2, *}$ a and Zong Woo Geem ${ }^{3, *(1)}$ \\ 1 Department of Social Housing, Gyeonggi Urban Innovation Corporation, Suwon 16556, Korea; \\ jhpark1@gico.or.kr \\ 2 School of Urban Planning \& Real Estate Studies, Dankook University, Yongin 16890, Korea \\ 3 College of IT Convergence, Gachon University, Seongnam 13120, Korea \\ * Correspondence: jsyu@dankook.ac.kr (J.-S.Y.); zwgeem@gmail.com (Z.W.G.)
}

Received: 22 December 2019; Accepted: 13 January 2020; Published: 14 January 2020

\begin{abstract}
Although Korea has made notable progress in the availability of public rental housing, Korea's public rental housing representing $6.3 \%$ of the country's total housing is still below the $8 \%$ OECD average from 2016. The Seoul Metropolitan Area (composed of Seoul City, Incheon City, and Gyeonggi Province) has nearly $50 \%$ of the country's population, but $11 \%$ of the nation's territory, meaning the area suffers from an acute shortage of public rental housing. This is a serious problem which is hampering the sustainability of Korean society in general. We will examine the possibility of improving this public housing problem using certain algorithms to optimize decision making and resource allocation. This study reviews two pioneering studies on optimal investment portfolio for land development projects and optimal project combination for urban regeneration projects, and then optimizes a public housing investment combination to maximize the amount of public rental houses in Gyeonggi province using optimization techniques. Through the optimal investment combination, public rental houses were found to be more efficiently and sustainably planned for the community.
\end{abstract}

Keywords: public rental house; sustainability; optimal project combination; genetic algorithm; branch \& bound method

\section{Introduction}

Korea's record for improving access to quality housing has been significant. This has been partially due to the introduction of minimum living standards (e.g., the number of rooms and floor space being differentiated by the size and composition of households) and by direct government support for housing construction. However, although the long-term public rental housing inventory has been steadily rising over the last decade, its share (6.3\%) of total housing in 2016 is still below the OECD average $(8 \%)$ according to the Korean Ministry of Land, Infrastructure, and Transport [1,2]. South Korea aims to increase the share of public rental housing to $9 \%$ by 2022 [1].

The scarcity of developable land for residential purposes in South Korea is more problematic in urban areas such as Seoul. The Seoul Metropolitan Area (SMA) — composed of Seoul city, Incheon city, and Gyeonggi province-represents $11 \%$ of Korea's territory and accommodates almost 50\% of the national population. As a result, housing demand in SMA is very high [2]. Strong demand, geographical constraint, and extensive land use regulation, such as greenbelt policy, may be leading to high house prices in SMA. Young, senior, and low-income households are particularly affected by soaring house prices in this region. The supply of public rental housing helps to solve this problem by expanding the stock of affordable housing, and it also indirectly contributes by keeping a lid on private rent prices.

According to Housing Welfare Road map [1], total housing stock increased by 3.58 million (22.0\%) from 16.3 million in 2007 to 19.88 million in 2016 but housing prices increased by $24.9 \%$, meaning it is 
not easy for ordinary people to buy houses. The Price to Income Ratio (PIR) is 5.6 and the PIR for the lowest-income group is 9.8 in South Korea.

So far, researchers have performed useful studies in the field of land-project optimization and public rental housing supply using optimization techniques such as the genetic algorithm (GA) and branch and bound method (B\&B).

The genetic algorithm is useful tool which has been used to find the spatial optimization of multi-objective and multi-site land use allocation [3], to forecast the private housing demand in Hong Kong [4], to search for optimal solutions to a land use allocation problem with multiple objectives and constraints in case of Tongzhou Newtown in Beijing, China [5], to formulate and develop municipal land use plans in Galicia, Spain [6], and to undertake land-use spatial optimization in Gaoqiao Town, Zhejiang Province, China [7]. The genetic algorithm has also been used to maximize land prices and reduce incompatibility among land uses of an area for urban planners [8], enhance real estate appraisal forecasting with ridge regression [9], optimize transportation infrastructure planning in Provo, Utah, USA [10] or urban land-use allocation in the case study of Dhanmondi Residential Area, Dhaka, Bangladesh [11], search for a spatial multi-objective land use optimization model [12], solve multi-objective land use planning in the Netherlands [13], and support simulating multi-objective spatial optimization allocation of land in Changsha, Zhuzhou, Xiangttan city in China [14].

While the above studies used GA in real estate problems, other researchers have used other intelligent techniques. Jin and $\mathrm{Yu}$ [15] analyzed the risk of housing rearrangement projects using the technique of fuzzy theory [16], and Bae and Yu [17] predicted apartment housing prices using the technique of machine learning [18].

There are two pioneering studies in real estate optimization for South Korean projects. The first one considered the optimal investment portfolio for land development projects [19], and the second one considered the optimal project combination for urban regeneration projects [20]. Both studies used both the genetic algorithm and the branch and bound method to obtain combinatorial optimization solutions in real estate cases. Park et al. [21] also proposed an optimization model for another type of real estate problem involving investment scheduling for public rental housing projects. However, their initial study has the limitation of not considering real-world cases. Thus, this study aims to focus more on practical approach in investment optimization for public rental housing projects by considering real-world project data in South Korea.

\section{Methodologies}

The genetic algorithm is the optimal problem-solving method, and it involves using the natural selection phenomenon together with genetics-related operators such as crossover, mutation, and reproduction. The branch and bound method is a technique used for discrete and combinatorial optimization problems.

\subsection{Genetic Algorithm}

The Genetic algorithm was first introduced by John Holland in the 1960s [21]. GA is a technique for moving from one population of 'chromosomes' to a new population using selection operators such as crossover, mutation, and inversion. Each chromosome is composed of 'genes (digital bits)', and each gene is filled with a particular 'allele (zero or one)'. In the selection operation, a group of chromosomes that are allowed to be reproduced is selected in the population, and the fitter chromosomes have a higher chance to produce offspring. Crossover exchanges subparts of two chromosomes, generally mimicking biological recombination between two chromosome organisms. Afterwards, mutation arbitrary changes the values of some places in the chromosomes and inversion reverses the order of an adjacent section of the chromosome, thus rearranging the order in which genes are spread. 


\subsection{Branch and Bound Method}

The Branch and Bound method (B\&B) was developed independently by Land and Doig in 1960 and by Murty, Karel, and Little in 1962 [19]. B\&B is an analytical approach for discrete optimization problems. Unlike continuous optimization problems, discrete optimization problems are not smooth functions because integer restrictions are placed on (at least some of) the relevant variables. Discrete optimization problems are solved by enumerative methods that investigate the feasible solution set. $B \& B$ is an attractive partial enumeration strategy for optimization problems because it analyzes each subgroup with a lower bound or upper bound (branching and bounding) and deletes some groups with no feasibility (pruning), thus finding optimal combination in remaining groups (retracting). Therefore, B\&B has four steps as follows: (1) branching, (2) bounding, (3) pruning, and (4) retracting.

\section{Optimization for Land Development Projects}

One of pioneering studies in public real estate optimization in South Korea focused on land development planning [19]. The summary of the study can be reviewed as follows.

Government-owned public companies often have a chance to decide the most reasonable investment portfolio from a number of new projects under a limited budget. Here, the limited budget can be a major constraint in this study. Another constraint in land development problems is the balance between profitability and public interest. If a public company chooses projects with a high profit margin but low public interest in order to maximize the total return on investment, its role for public good is likely to be reduced.

The third constraint in land optimization is the equitability in each region. If a project is concentrated on a specific region, it may be criticized for not focusing on regionally balanced development. The fourth constraint is the balance among land use purposes, such as new town, public rental housing, and industrial complexes. There is a minimally required amount constraint for each purpose.

The fifth constraint involves efficient allocation of human resources. Regarding human resources, it is necessary to minimize unassigned employees in order to maintain employment. The sixth constraint is the possibility of joint investment from cooperated companies. While there are some projects that can be jointly performed with a shared budget and risk, there are other projects that must be solely completed by a single company.

It is very important to find the best investment combination that will allow public companies to properly allocate financial resources and maximize return on investment among many new projects while meeting the constraints described above. It is not easy to rationally derive the optimal business combination that maximizes the return on investment among many new projects or maximizes the public interest while meeting the minimum profit goal because there is currently no customized methodology for achieving this in South Korea. As such, we must rely on the optimal business combination (combinatorial optimization) that maximizes the return on investment while meeting multiple constraints from a group of new project candidates that have different characteristics.

In line with the above-mentioned factors (return on investment maximization, budget limitation, public interest consideration, regional balance, land purpose balance, human resource management, joint investment possibility), an optimal land development model was proposed as follows:

- Objective function: Max $\sum_{i}\left(R_{i} \cdot X_{i}\right)$ : maximization of the return on investment $\left(R_{i}\right.$ is the return on investment (\%) for project $i)$

- Decision variable: $X_{i}$ : the investment amount on project $i$ (unit: $10^{10} \mathrm{KRW}$ )

- Constraint 1. $\sum_{i} X_{i} \leq 110$ : the total investment amount is equal to or less than $110 \times 10^{10} \mathrm{KRW}$

- Constraint 2. $\sum_{k} X_{k} \geq 0.3 \sum_{i} X_{i}, k \in$ Set of non-for-profit projects: the investment for non-for-profit projects is equal to or more than $30 \%$ of total investment

- Constraint 3. $\sum_{k} X_{k} \leq 0.4 \sum_{i} X_{i}, k \in\{$ East, West, North, South\}: the investment in each area is equal to or less than $40 \%$ of total investment 
- Constraint 4. $\sum_{k} X_{k} \geq 0.2 \sum_{i} X_{i}, k \in\{$ New Town, Public Housing, Industrial Complex\}: investment in each business division is equal to or more than $20 \%$ of total investment

- Constraint 5. $\sum_{i} N_{i} \cdot \operatorname{Sgn}\left(X_{i}\right) \geq 250$ : total employees in active projects are equal to or more than $250\left(N_{i}\right.$ is the number of employees for performing project $i$; $\operatorname{Sgn}()$ is a sign function representing the sign ( 0 or 1$)$ of $X_{i}$ )

- Constraint 6. $0 \leq X_{i} \leq X_{i}^{\text {Upper }}$ and $X_{i}$ is an integer if $i$ is a joint project. $X_{i}=0$ or $X_{i}=X_{i}^{\text {Upper }}$ if $i$ is not a joint project. Projects that cannot be jointly invested such as E, F, G, H, M, N, O, P, S, and T have only two selections such as no investment or whole investment, while projects that can be jointly invested such as A, B, C, D, I, J, K, L, Q, and R have a partial investment option.

Park et al. [19] also provided a dataset of 20 new candidate projects in South Korea, as shown in Table 1. Each project has different characteristic in terms of investment amount, profit, public interest, investment area, business division, number of employees participated, and joint investment possibility.

Table 1. Candidate Land Development Projects.

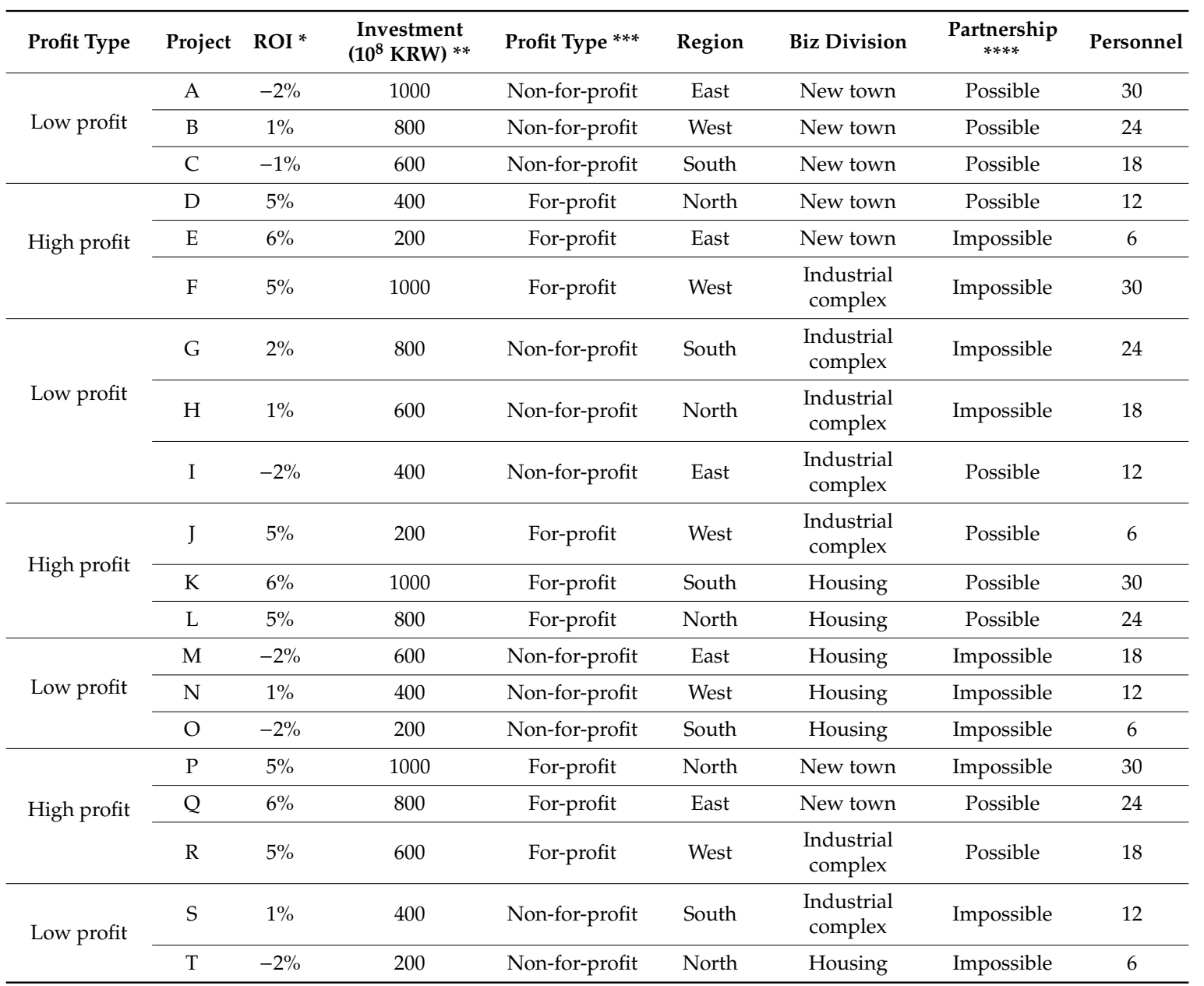

* ROI was assumed based on real project performances. ${ }^{* *}$ Total investment amount is 1.2 trillion KRW, which is over the total investment budget of 1.1 trillion Korean Won (KRW). ${ }^{* *}$ Non-for-profit: New town projects that are not for profit but are for regional balance development; Public rental housing and Industrial complex projects that are not for profit but are for regional balance development. / For-profit: New town projects in attractive location; Public sale housing and Industrial complexes in attractive locations. ${ }^{* * *}$ Local government-owned company may invest with other public land development companies to reduce financial burden and business risk if partnerships are possible.

This optimization model has 20 decision variables, each of which has an integer or binary number, and the total number of possible candidate solutions is $3.3 \times 10^{11}$, which requires a considerable computation process. 
After computation, this land development planning model found an optimal profit of 3.58 $\left(10^{10} \mathrm{KRW}\right)$, as shown in Table 2, which also satisfies the constraints as follows:

Table 2. Result of Land Development Optimization.

\begin{tabular}{|c|c|c|c|c|c|c|c|c|c|c|c|}
\hline \multirow{2}{*}{ Project } & \multirow{2}{*}{$\begin{array}{c}\text { Investment } \\
\text { Amount }\end{array}$} & \multirow{2}{*}{$\begin{array}{l}\text { Non-for- } \\
\text { Profit }\end{array}$} & \multicolumn{4}{|c|}{ Project Area } & \multicolumn{3}{|c|}{ Business Division } & \multirow{2}{*}{ Person } & \multirow{2}{*}{$\begin{array}{c}\text { Profit (10 } \\
\text { billion KRW) }\end{array}$} \\
\hline & & & East & West & South & North & New Town & $\begin{array}{l}\text { Industrial } \\
\text { Complex }\end{array}$ & Housing & & \\
\hline B & 8 & 8 & - & 8 & - & - & 8 & - & - & 24 & 0.08 \\
\hline $\mathrm{C}$ & - & - & - & - & - & - & - & - & - & - & - \\
\hline $\mathrm{F}$ & 10 & - & - & 10 & - & - & - & 10 & - & 30 & 0.5 \\
\hline G & 8 & 8 & - & - & 8 & - & - & 8 & - & 24 & 0.16 \\
\hline $\mathrm{H}$ & 6 & 6 & - & - & - & 6 & - & 6 & - & 18 & 0.06 \\
\hline I & - & - & - & - & - & - & - & - & - & - & - \\
\hline $\mathrm{M}$ & - & - & - & - & - & - & - & - & - & - & - \\
\hline $\mathrm{N}$ & 4 & 4 & - & 4 & - & - & - & - & 4 & 12 & 0.04 \\
\hline $\mathrm{O}$ & - & - & - & - & - & - & - & - & - & - & - \\
\hline $\mathrm{P}$ & 10 & - & - & - & - & 10 & 10 & - & - & 30 & 0.5 \\
\hline $\mathrm{Q}$ & 8 & - & 8 & - & - & - & 8 & - & - & 24 & 0.48 \\
\hline $\mathrm{R}$ & 6 & - & - & 6 & - & - & - & 6 & - & 18 & 0.3 \\
\hline $\mathrm{S}$ & 4 & 4 & - & - & 4 & - & - & 4 & - & 12 & 0.04 \\
\hline $\mathrm{T}$ & - & - & - & - & - & - & - & - & - & - & - \\
\hline
\end{tabular}

- Total investment amount: $90\left(10^{10} \mathrm{KRW}\right)$ which is less than $110\left(10^{10} \mathrm{KRW}\right)$.

- Non-for-profit ratio: $33 \%$ which is more than $30 \%$ of total investment.

- Investment area: East (10), West (30), South (22), North (28). Each area has less than $36\left(10^{10}\right.$ KRW) which is $40 \%$ of total investment.

- Investment division: new town (32), industrial complex (36), public housing (22). Each division is more than $18\left(10^{10} \mathrm{KRW}\right)$, which is $20 \%$ of total investment.

- Number of employees: 270 which is more than 250.

\section{Optimization for Urban Regeneration Projects}

Another pioneering study in public real estate optimization in South Korea is urban regeneration planning [20]. The summary of this study can be reviewed as follows.

According to Lee and Lim [22], urban growth in South Korea has reached its limit, and urban areas have started to decline. Urban decline has resulted in critical issues such as outflow of the population, ageing infrastructure, loss of economic capacity, etc. Thus, the 'urban regeneration' can be a new strategy in South Korea's national urban policy for maintaining sustainable urban circumstances and revitalizing enervated communities. This concept of urban regeneration is not only for city planning-oriented approaches which can develop sustainable economic and physical city environments, but also for social and governance-oriented practices which can accumulate social capital. Thus, South Korea's urban regeneration policy is highly related to the idea of urban sustainability.

There are various models such as the 'Downtown model (DM)', 'Economic support model (ESM)', and 'Public company proposal model (PCPM)' for urban regeneration projects. The DM is a project model used to support the recovery of public functions and the vitalization of commerce through cooperation with historical, cultural, and traveling resources in old downtown areas where the decline 
of public services and the decline of commerce are severe. The ESM is a project model that creates new industrial complexes to increase jobs in areas where urban decline is severe. The PCPM has been proposed by public companies as a plan for urban regeneration in certain cities, while other models were proposed by local governments.

Each project can be evaluated based on various criteria and correspondingly earned certain scores, as shown in Table 3.

Table 3. Evaluation Criteria and Score for Urban Regeneration Projects [23].

\begin{tabular}{|c|c|c|c|}
\hline Evaluation Criteria & Score Points & Detail Evaluation Criteria & Score Points \\
\hline \multirow{2}{*}{$\begin{array}{l}\text { Urgency and Necessity } \\
\text { of project }\end{array}$} & \multirow{2}{*}{30} & Urgency of project (Region deterioration, Safety) & 15 \\
\hline & & Necessity of project (Community participation) & 15 \\
\hline \multirow{4}{*}{ Feasibility of project plan } & \multirow{4}{*}{40} & Local government's organization for project & 5 \\
\hline & & Relevance of project plan & 10 \\
\hline & & Plan of land acquisition and finance for project & 15 \\
\hline & & Community participation and empowerment training & 10 \\
\hline \multirow{4}{*}{ Effect of project } & \multirow{4}{*}{30} & Housing welfare and improvement of quality of life & 10 \\
\hline & & Job creation effect & 10 \\
\hline & & Social integration and sustainability & 5 \\
\hline & & $\begin{array}{c}\text { Countermeasure towards side-effects of the real } \\
\text { estate market }\end{array}$ & 5 \\
\hline
\end{tabular}

The South Korean central government plans to choose 13 DM projects, 2 ESM projects, and 10 PCPM projects from a total of 66 projects developed by 16 local governments based on the evaluation of the Urban Regeneration Special Committee. Here, each local government can apply for a maximum of four projects. If the central government selects projects with respect to project effects themselves, there will be unselected regions, which will violate the principle of regionally balanced development. For this reason, a combinatorial optimization model was proposed and could provide optimal solutions while satisfying various constraints.

The model for optimally selecting urban regeneration projects can be formulated as follows:

- Objective function: Max $\sum_{i}\left(S_{i} \cdot X_{i}\right)$ : maximization of urban regeneration effect $\left(S_{i}\right.$ is earned score for project $i$ )

- Decision variable: $X_{i} \in\{0,1\}$ : investment decision for project $i$ ( 1 means investment; and 0 means no investment)

- Constraint 1. $\sum_{k} X_{k}=13, k \in$ Set of downtown-focused projects

- Constraint 2. $\sum_{k} X_{k}=2, k \in$ Set of industry-oriented projects

- Constraint 3. $\sum_{k} X_{k}=10, k \in$ Set of public-corporation-proposed projects

- Constraint 4. $1 \leq \sum_{j} X_{j} \leq 3, j \in$ Set of non-Gyeonggi province projects (Projects should be selected in each local government from a minimum of one project to a maximum of three for regionally balanced development)

- Constraint 5. $2 \leq \sum_{j} X_{j} \leq 4, j \in$ Set of Gyeonggi province projects (Because Gyeonggi province has lots of urban regeneration demand, projects should be selected from a minimum of two projects to a maximum of four)

Total number of candidate solutions for this combinatorial problem including constraint-violated ones is $2^{66}\left(\approx 7.38 \times 10^{19}\right)$, which actually requires a major computation process.

The results of this optimal project combination problem using GA and B\&B are shown in Tables 4-6. The total score (2198) from B\&B as shown in Table 5 is slightly better than that (2173) of GA as shown in Table 4, and Table 6 shows the overall result from B\&B. Here, Busan stands for Busan Metropolitan City, Daegu stands for Daegu Metropolitan City, Incheon stands for Incheon Metropolitan City, Gwangju stands for Gwangju Metropolitan City, Daejeon stands for Daejeon Metropolitan City, Ulsan stands for 
Ulsan Metropolitan City, Jeju stands for the Jeju Special Self-governing Province, and Sejong stands for the Sejong Special Self-governing City.

Table 4. Selected Projects of Urban Regeneration Planning using GA.

\begin{tabular}{cc}
\hline Project Model (Number) & Project Name \\
\hline DM (13) & B1, C1, E1, F2, G3, H1, J2, K1, M1, M2, N1, O1, P1 \\
\hline ESM (2) & A4, B4 \\
\hline PCPM (10) & C3, D3, F3, G4, H2, I2, J3, K2, L3, M3 \\
\hline
\end{tabular}

Table 5. Selected Projects of Urban Regeneration Planning using B\&B.

\begin{tabular}{cc}
\hline Project Model (Number) & Project Name \\
\hline DM (13) & B1, C1, E1, F2, G2, G3, H1, K1, L2, N1, O1, P1, P2 \\
\hline ESM (2) & D4, K4 \\
\hline PCPM (10) & A3, H2, I2, J3, K2, L3, M3, N2, O2, P3 \\
\hline
\end{tabular}

Table 6. Overall Result of Urban Regeneration Planning using B\&B.

\begin{tabular}{|c|c|c|c|c|c|c|c|}
\hline $\begin{array}{l}\text { Local Govt. } \\
\text { (Number) }\end{array}$ & $\begin{array}{l}\text { Project } \\
\text { Name }\end{array}$ & $\begin{array}{l}\text { Project } \\
\text { Model }\end{array}$ & $\begin{array}{c}\text { Score of } \\
\text { Evaluation }\end{array}$ & $\begin{array}{l}\text { Local Govt. } \\
\text { (Number) }\end{array}$ & $\begin{array}{l}\text { Project } \\
\text { Name }\end{array}$ & $\begin{array}{l}\text { Project } \\
\text { Model }\end{array}$ & $\begin{array}{l}\text { Score of } \\
\text { Evaluation }\end{array}$ \\
\hline \multirow{4}{*}{ Busan (1) } & A1 & $\mathrm{DM}$ & 74 & \multirow{4}{*}{$\begin{array}{l}\text { Chungcheong } \\
\text { (North) (1) }\end{array}$} & I1 & $\mathrm{DM}$ & 73 \\
\hline & $\mathrm{A} 2$ & DM & 76 & & $\mathrm{I} 2$ & PCPM & 89 \\
\hline & A3 & PCPM & 86 & & $\mathrm{I} 3$ & ESM & 84 \\
\hline & A4 & ESM & 83 & & $\mathrm{I} 4$ & ESM & 76 \\
\hline \multirow{4}{*}{ Daegu (1) } & B1 & DM & 83 & \multirow{4}{*}{$\begin{array}{l}\text { Chungcheong } \\
\text { (South) (1) }\end{array}$} & $\mathrm{J} 1$ & DM & 79 \\
\hline & B2 & DM & 83 & & $\mathrm{~J} 2$ & DM & 82 \\
\hline & B3 & PCPM & 80 & & J3 & PCPM & 91 \\
\hline & B4 & ESM & 83 & & $\mathrm{~J} 4$ & ESM & 79 \\
\hline \multirow{4}{*}{ Incheon (1) } & $\mathrm{C} 1$ & DM & 88 & \multirow{4}{*}{$\begin{array}{c}\text { Jeolla (North) } \\
\text { (3) }\end{array}$} & K1 & DM & 88 \\
\hline & $\mathrm{C} 2$ & $\overline{\mathrm{DM}}$ & 73 & & K2 & PCPM & 94 \\
\hline & C3 & PCPM & 86 & & K3 & ESM & 79 \\
\hline & $\mathrm{C} 4$ & ESM & 75 & & K4 & ESM & 86 \\
\hline \multirow{4}{*}{ Gwangju (1) } & D1 & DM & 74 & \multirow{4}{*}{$\begin{array}{c}\text { Jeolla (South) } \\
\text { (2) }\end{array}$} & L1 & DM & 81 \\
\hline & D2 & DM & 73 & & L2 & DM & 85 \\
\hline & D3 & PCPM & 84 & & L3 & PCPM & 92 \\
\hline & D4 & ESM & 83 & & L4 & ESM & 79 \\
\hline \multirow{4}{*}{ Daejeon (1) } & E1 & $\overline{\mathrm{DM}}$ & 92 & \multirow{4}{*}{$\begin{array}{l}\text { Gyeongsang } \\
\text { (North) (1) }\end{array}$} & M1 & DM & 79 \\
\hline & E2 & $\mathrm{DM}$ & 84 & & M2 & $\mathrm{DM}$ & 82 \\
\hline & E3 & PCPM & 83 & & M3 & PCPM & 92 \\
\hline & $\mathrm{E} 4$ & ESM & 82 & & M4 & ESM & 78 \\
\hline \multirow{4}{*}{ Ulsan (1) } & F1 & DM & 73 & \multirow{4}{*}{$\begin{array}{l}\text { Gyeongsang } \\
\text { (South) (2) }\end{array}$} & N1 & DM & 85 \\
\hline & $\mathrm{F} 2$ & DM & 86 & & N2 & PCPM & 89 \\
\hline & F3 & PCPM & 85 & & N3 & ESM & 84 \\
\hline & $\mathrm{F} 4$ & ESM & 77 & & N4 & ESM & 84 \\
\hline \multirow{6}{*}{ Gyeonggi (2) } & G1 & $\mathrm{DM}$ & 80 & \multirow{4}{*}{ Jeju (2) } & O1 & DM & 87 \\
\hline & G2 & $\overline{\mathrm{DM}}$ & 82 & & $\mathrm{O} 2$ & PCPM & 90 \\
\hline & G3 & $\mathrm{DM}$ & 86 & & $\mathrm{O} 3$ & ESM & 81 \\
\hline & G4 & PCPM & 85 & & $\mathrm{O} 4$ & ESM & 80 \\
\hline & G5 & ESM & 81 & \multirow{4}{*}{ Sejong (3) } & P1 & DM & 87 \\
\hline & G6 & ESM & 83 & & P2 & DM & 83 \\
\hline \multirow{4}{*}{ Gangwon (2) } & $\mathrm{H} 1$ & $\overline{\mathrm{DM}}$ & 95 & & P3 & PCPM & 90 \\
\hline & $\mathrm{H} 2$ & PCPM & 89 & & $\mathrm{P} 4$ & ESM & 77 \\
\hline & $\mathrm{H} 3$ & ESM & 81 & & & & \\
\hline & $\mathrm{H} 4$ & ESM & 83 & & & & \\
\hline
\end{tabular}




\section{Optimal Project Combination for Public Rental Housing}

While previous real estate optimization studies $[19,20]$ were based on artificial examples on investment amount, return on investment, the evaluation score for a urban regeneration project, etc., this study focused on a real-world case of a new town project in South Korea. We planned to find a optimal public housing investment combination to maximize the amount of public rental houses in Gwanggyo, which is one of the second-stage new towns. Gwanggyo new town is a planned city surrounding part of Suwon city and part of Yongin city. It is located $25 \mathrm{~km}$ south from Seoul, as shown with a red rectangle in Figure 1. In 2004, Gwanggyo new town was designated by Gyeonggi Province, Suwon city, Youngin city, and by a local-government-owned real-estate company named Gyeonggi Urban Innovation Corporation (GICO). Gwanggyo new town, which will accommodate more than 31,000 households, was not only intended for the purpose of providing increased housing supply but also for several regional purposes such as a local-government office, convention center, and commercial zone.

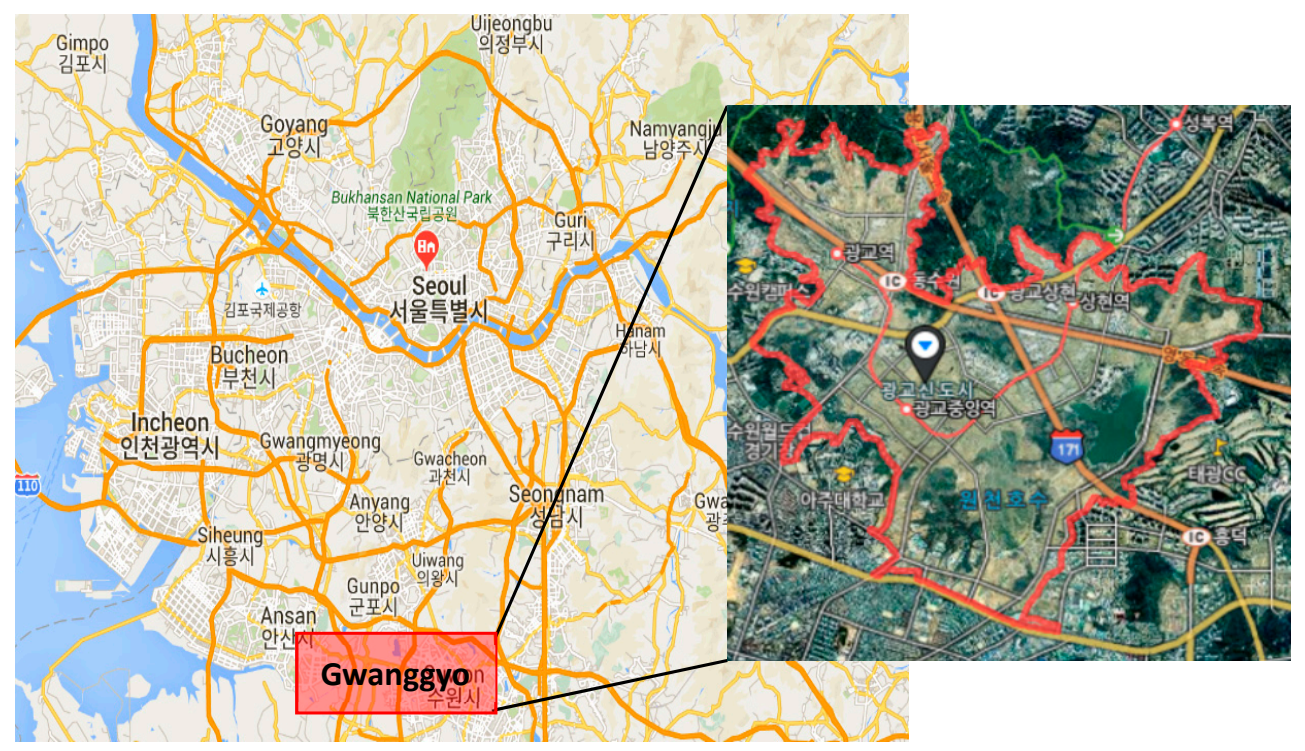

Figure 1. Map of Gwanggyo New Town (Google and Naver map).

The percentage of public rental housing investment from 2008 to 2018 by GICO was very low, and during this period the housing investment for public sale occupied most of relevant company activities, as seen in Table 7 (the data was extracted from an internal report).

Table 7. The Public Sale and Rental House Construction Record of GICO.

\begin{tabular}{|c|c|c|c|c|}
\hline Type & Housing Project & Construction Period & Investment $\left(10^{8}\right.$ KRW $)$ & Detail of Investment \\
\hline \multirow{9}{*}{ Sales Housing } & Sub Total & & 30,345 & \\
\hline & Gimpo-Yangchon & 2008.4 2010.12 & 437 & Land price + Construction cost \\
\hline & Gwanggyo Edu-town 13-15 & 2009.12 2012.12 & 2225 & Construction cost (GICO's land) \\
\hline & Gimpo-Hangang Ab-1 & 2009.12 2013.2 & 2617 & Land price + Construction cost \\
\hline & Wirye A2-11 & $2014.4 \sim 2016.9$ & 6758 & Land price + Construction cost \\
\hline & Wirye A2-2 & $2015.4 \sim 2017.9$ & 4661 & Land price + Construction cost \\
\hline & Namyangju-Dasan B2 & 2015.4 2017.11 & 2166 & Construction cost (GICO's land) \\
\hline & Namyangju-Dasan B4 & 2015.4 2017.11 & 2938 & Construction cost (GICO's land) \\
\hline & Namyangju-Dasan S1 & 2015.12 2018.6 & 2902 & Construction cost (GICO's land) \\
\hline
\end{tabular}


On the other hand, all the public rental houses located in Gwanggyo New Town were supplied by the Korea Land Housing Corporation (KLHC), which is the central government-owned company with more than 32 trillion KRW of capital as of the first half of 2019 (www.lh.or.kr). GICO, who had about 1.6 trillion KRW of capital as of the first half of 2019 (www.gico.or.kr), did not build any public rental houses in Gwanggyo New Town. Because GICO had more than 4 trillion KRW of loans resulting from land acquisition and development expense with regard to Gwanggyo New Town from 2012 to 2014, it had to sell land for public rental housing to KLHC rather than construct and operate public rental houses. Table 8 shows the list of public rental house projects developed by KLHC and the corresponding construction costs. But it would be more desirable for GICO to supply some public rental houses to satisfy its mission statement. If the GICO had used 3034.5 billion won, which was originally invested for the 10 public sale house projects from 2008 to 2018, to construct rental houses and sales houses instead, it would have been a better decision that met the purpose of public interest.

Table 8. Estimated Cost of Public Rental House Projects.

\begin{tabular}{|c|c|c|c|c|c|}
\hline Site Name & Number of Houses & Construction Completion & $\begin{array}{c}\text { Total Area }\left(\mathrm{m}^{2}\right) \\
\text { (A) }\end{array}$ & $\begin{array}{l}\text { Estimated Construction } \\
\text { Cost }(K R W) \text { per } m^{2}(B)\end{array}$ & $\begin{array}{l}\text { Total Construction Cost } \\
\left(10^{8} \mathrm{KRW}\right) \text { of GICO }\end{array}$ \\
\hline Total & 6956 & & 804,656 & & 8673 \\
\hline A11 & 637 & 2013.11 & 102,334 & \multirow{6}{*}{$1,077,893$} & 1103 \\
\hline A16 & 224 & 2014.7 & 34,680 & & 374 \\
\hline A24 & 394 & 2014.2 & 54,883 & & 592 \\
\hline A25 & 146 & 2011.10 & 13,091 & & 141 \\
\hline A26 & 1132 & 2013.12 & 172,477 & & 1859 \\
\hline A30 & 2091 & 2011.12 & 163,752 & & 1765 \\
\hline
\end{tabular}

According to a study on housing policy in South Korea [24], Korean housing authorities focused on the expansion of state-developed housing for sale rather than the provision of rental accommodation. In order to obtain adequate housing for poor and disadvantaged groups, adequate rental accommodation is needed to ensure legal security of tenure protection from discrimination and equal access to adequate housing for all persons and their families.

Here, the total number of combinations with 10 sales of housing sites and 10 rental housing sites (one rental housing project was developed by GICO as seen in Table 7 and nine projects were developed by KLHC as seen in Table 8 ) was $2^{20}$ because we had to decide whether or not to select each of 20 housing projects. Thus, instead of total enumeration, we utilized optimization techniques such as GA and B\&B to find an optimal solution.

The objective function and constraints for this housing combinatorial problem were as follows:

- Objective function: Max $\sum_{i}\left(N_{i} \cdot X_{i}\right)$ : Maximization of the number of supplied public rental houses $\left(N_{i}\right.$ is the number of supplied houses from project $i$ )

- Decision variable: $X_{i} \in\{0,1\}$ : investment decision for project $i$ (1 means investment; and 0 means no investment)

- Constraint 1: $\sum_{i}\left(B_{i} \cdot X_{i}\right) \leq 3034.5$ : Total investment amount should be less than 3034.5 billion $\mathrm{KRW}$, which is the total investment amount for public sale house projects from 2008 to 2018 ( $B_{i}$ is budget for project $i$ )

- Constraint 2. $\sum_{k} X_{k}=9, k \in$ Set of public sale house projects: By slightly reducing the number of public sale house projects from 10 to 9 , GICO can increase public rental houses more.

\subsection{Public Rental Housing Planning by Arbitrary Selection \#1}

GICO usually invests two public sale house projects per one new town, for example Gimpo-Hangang Ab-1 and Ab-7 in Gimpo-Hangang new town, Wirye A2-2, and Wirye A2-11 
in Wirye new town for their business portfolio. Gimpo-Yangchon (one project) and Namyangju-Dasan (three projects) are exceptional cases. Therefore, we excluded the biggest public sale house project, Namyangju-Dasan B4 among three Namyangju-Dasan projects. Then, we redistributed that investment amount of Namyangju-Dasan B4 (293,800 million KRW) to select public rental house projects. The result of arbitrary selection \#1 is shown in Table 9.

Table 9. Result of Arbitrary Selection \#1.

\begin{tabular}{|c|c|c|c|c|c|c|}
\hline & Name of Site & $\begin{array}{l}\text { Number of } \\
\text { Houses }\end{array}$ & $\begin{array}{c}\text { Investment } \\
\text { Amount (100m.) }\end{array}$ & Selection & $\begin{array}{c}\text { Number of } \\
\text { Selected Houses }\end{array}$ & $\begin{array}{c}\text { Investment } \\
\text { Amount }(100 \mathrm{~m} .)\end{array}$ \\
\hline \multirow{9}{*}{$\begin{array}{l}\text { Rental house } \\
\text { (10) }\end{array}$} & Gwanggyo A10 & 701 & 1196 & $x$ & - & - \\
\hline & Gwanggyo A11 & 637 & 1103 & $x$ & - & - \\
\hline & Gwanggyo A16 & 224 & 374 & $x$ & - & - \\
\hline & Gwanggyo A19 & 1373 & 1212 & $x$ & - & - \\
\hline & Gwanggyo A23 & 258 & 431 & $x$ & - & - \\
\hline & Gwanggyo A25 & 146 & 141 & $x$ & - & - \\
\hline & Gwanggyo A26 & 1132 & 1859 & $x$ & - & - \\
\hline & Gwanggyo A30 & 2091 & 1765 & $\mathrm{O}$ & 2091 & 1765 \\
\hline & Gimpo Ab-2 & 559 & 1091 & $x$ & - & - \\
\hline \multirow{9}{*}{$\begin{array}{l}\text { Sales house } \\
\text { (10) }\end{array}$} & Gwanggyo-Edutown 13 15 & 1173 & 2225 & $\mathrm{O}$ & 1173 & 2225 \\
\hline & Gimpo-Hangang Ab-1 & 1167 & 2617 & $\mathrm{O}$ & 1167 & 2617 \\
\hline & Gimpo-Hangang Ab-7 & 1382 & 3028 & $\mathrm{O}$ & 1382 & 3028 \\
\hline & Wirye A2-11 & 1540 & 6758 & $\mathrm{O}$ & 1540 & 6758 \\
\hline & Wirye A2-2 & 1413 & 4661 & $\mathrm{O}$ & 1413 & 4661 \\
\hline & Namyangju-Dasan B2 & 1186 & 2166 & $\mathrm{O}$ & 1186 & 2166 \\
\hline & Namyangju-Dasan B4 & 1615 & 2938 & $x$ & - & - \\
\hline & Namyangju-Dasan S1 & 1685 & 2902 & $\mathrm{O}$ & 1685 & 2902 \\
\hline & Sub Total & 13,668 & 30,345 & 9 sites selected & 12,053 & 27,407 \\
\hline
\end{tabular}

As observed in Table 9, Constraint 1 is satisfied because total investment amount is 2,917,200 million KRW, which is less than 3,034,520 million KRW. Also, Constraint 2 is satisfied because only Namyangju-Dasan B4 was excluded.

The result of the objective function (maximization of the number of suppled public rental houses) is 2091. If GICO also includes Gwanggyo A19, the biggest remaining public rental house project, the total investment amount would be 3,384,000 million KRW which violates Constraint $1(\leq 3,034,500$ million KRW).

\subsection{Public Rental Housing Planning by Arbitrary Selection \#2}

GICO excludes Wirye A2-11 (whose investment amount was the biggest) to supply more public rental houses. Then, GICO redistributes that investment amount of Wirye A2-11 (675,800 million KRW) in order to maximize the number of selected houses. The result of arbitrary selection \#2 is as shown in Table 10.

As observed in Table 10, Constraint 1 is satisfied because total investment amount is 2,961,900 million KRW which is less than 3,034,520 million KRW. Also, Constraint 2 is satisfied because only Wirye A2-11 is excluded.

The result of objective function (maximization of the number of suppled public rental houses) is 5297. If GICO also includes Gwanggyo A11, the biggest remaining public rental house project, 
total investment amount would be 3,722,000 million KRW, which violates Constraint $1(\leq 3,034,500$ million KRW).

Table 10. Result of Arbitrary Selection \#2.

\begin{tabular}{|c|c|c|c|c|c|c|}
\hline & Name of Site & $\begin{array}{l}\text { Number of } \\
\text { Houses }\end{array}$ & $\begin{array}{c}\text { Investment } \\
\text { Amount (100m.) }\end{array}$ & Selection & $\begin{array}{c}\text { Number of } \\
\text { Selected Houses }\end{array}$ & $\begin{array}{c}\text { Investment } \\
\text { Amount }(100 \mathrm{~m} .)\end{array}$ \\
\hline \multirow{9}{*}{$\begin{array}{l}\text { Rental house } \\
\text { (10) }\end{array}$} & Gwanggyo A10 & 701 & 1196 & $\mathrm{O}$ & 701 & 1196 \\
\hline & Gwanggyo A11 & 637 & 1103 & $x$ & - & - \\
\hline & Gwanggyo A16 & 224 & 374 & $x$ & - & - \\
\hline & Gwanggyo A19 & 1373 & 1212 & $\mathrm{O}$ & 1373 & 1212 \\
\hline & Gwanggyo A23 & 258 & 431 & $x$ & - & - \\
\hline & Gwanggyo A25 & 146 & 141 & $x$ & - & - \\
\hline & Gwanggyo A26 & 1132 & 1859 & $\mathrm{O}$ & 1132 & 1859 \\
\hline & Gwanggyo A30 & 2091 & 1765 & $\mathrm{O}$ & 2091 & 1765 \\
\hline & Gimpo Ab-2 & 559 & 1091 & $x$ & - & - \\
\hline \multirow{9}{*}{$\begin{array}{l}\text { Sales house } \\
\quad(10)\end{array}$} & Gwanggyo-Edutown 13 15 & 1173 & 2225 & $\mathrm{O}$ & 1173 & 2225 \\
\hline & Gimpo-Hangang Ab-1 & 1167 & 2617 & $\mathrm{O}$ & 1167 & 2617 \\
\hline & Gimpo-Hangang Ab-7 & 1382 & 3028 & $\mathrm{O}$ & 1382 & 3028 \\
\hline & Wirye A2-11 & 1540 & 6758 & $x$ & - & - \\
\hline & Wirye A2-2 & 1413 & 4661 & $\mathrm{O}$ & 1413 & 4661 \\
\hline & Namyangju-Dasan B2 & 1186 & 2166 & $\mathrm{O}$ & 1186 & 2166 \\
\hline & Namyangju-Dasan B4 & 1615 & 2938 & $\mathrm{O}$ & 1615 & 2938 \\
\hline & Namyangju-Dasan S1 & 1685 & 2902 & $\mathrm{O}$ & 1685 & 2902 \\
\hline & Sub Total & 13,668 & 30,345 & 9 sites selected & 12,128 & 23,587 \\
\hline
\end{tabular}

\subsection{Public Rental Housing Planning Determined by the Branch and Bound Method}

The result of the Branch and Bound Method is shown in Table 11. As observed in Table 11, Constraint 1 is satisfied because total investment amount is 2,929,800 million KRW, which is less than 3,034,520 million KRW. Also, Constraint 2 is satisfied because only Wirye A2-11 is excluded.

Table 11. Result of Branch \& Bound Method.

\begin{tabular}{|c|c|c|c|c|c|c|}
\hline & Name of Site & $\begin{array}{c}\text { Number of } \\
\text { Houses }\end{array}$ & $\begin{array}{c}\text { Investment } \\
\text { Amount (100m.) }\end{array}$ & Selection & $\begin{array}{c}\text { Number of } \\
\text { Selected Houses }\end{array}$ & $\begin{array}{c}\text { Investment } \\
\text { Amount (100m.) }\end{array}$ \\
\hline \multirow{11}{*}{$\begin{array}{l}\text { Rental house } \\
\text { (10) }\end{array}$} & Gwanggyo A10 & 701 & 1196 & $\mathrm{O}$ & 701 & 1196 \\
\hline & Gwanggyo A11 & 637 & 1103 & $x$ & - & - \\
\hline & Gwanggyo A16 & 224 & 374 & $\mathrm{O}$ & 224 & 374 \\
\hline & Gwanggyo A19 & 1373 & 1212 & $\mathrm{O}$ & 1373 & 1212 \\
\hline & Gwanggyo A23 & 258 & 431 & $\mathrm{O}$ & 258 & 431 \\
\hline & Gwanggyo A24 & 394 & 592 & $\mathrm{O}$ & 394 & 592 \\
\hline & Gwanggyo A25 & 146 & 141 & $\mathrm{O}$ & 146 & 141 \\
\hline & Gwanggyo A26 & 1132 & 1859 & $x$ & - & - \\
\hline & Gwanggyo A30 & 2091 & 1765 & $\mathrm{O}$ & 2091 & 1765 \\
\hline & Gimpo Ab-2 & 559 & 1091 & $x$ & - & - \\
\hline & Sub Total & 7515 & 9764 & 7 sites selected & 5187 & 5711 \\
\hline
\end{tabular}


Table 11. Cont.

\begin{tabular}{|c|c|c|c|c|c|c|}
\hline & Name of Site & $\begin{array}{l}\text { Number of } \\
\text { Houses }\end{array}$ & $\begin{array}{c}\text { Investment } \\
\text { Amount (100m.) }\end{array}$ & Selection & $\begin{array}{c}\text { Number of } \\
\text { Selected Houses }\end{array}$ & $\begin{array}{c}\text { Investment } \\
\text { Amount }(100 \mathrm{~m} .)\end{array}$ \\
\hline \multirow{9}{*}{$\begin{array}{l}\text { Sales house } \\
\text { (10) }\end{array}$} & Gwanggyo-Edutown 12 & 1764 & 2613 & $\mathrm{O}$ & 1764 & 2613 \\
\hline & Gwanggyo-Edutown 13 15 & 1173 & 2225 & $\mathrm{O}$ & 1173 & 2225 \\
\hline & Gimpo-Hangang Ab-1 & 1167 & 2617 & $\mathrm{O}$ & 1167 & 2617 \\
\hline & Gimpo-Hangang Ab-7 & 1382 & 3028 & $\mathrm{O}$ & 1382 & 3028 \\
\hline & Wirye A2-2 & 1413 & 4661 & $\mathrm{O}$ & 1413 & 4661 \\
\hline & Namyangju-Dasan B2 & 1186 & 2166 & $\mathrm{O}$ & 1186 & 2166 \\
\hline & Namyangju-Dasan B4 & 1615 & 2938 & $\mathrm{O}$ & 1615 & 2938 \\
\hline & Namyangju-Dasan S1 & 1685 & 2902 & $\mathrm{O}$ & 1685 & 2902 \\
\hline & Sub Total & 13,668 & 30,345 & 9 sites selected & 12,128 & 23,587 \\
\hline
\end{tabular}

The result of objective function (maximization of the number of suppled public rental houses) is 5187.

\subsection{Public Rental Housing Planning by Genetic Algorithm}

The result of the Genetic Algorithm is shown in Table 12. As observed in Table 12, Constraint 1 is satisfied because total investment amount is 3,025,900 million KRW which is less than 3,034,520 million KRW. Also, Constraint 2 is satisfied because only Wirye A2-11 is excluded.

Table 12. Result of the Genetic Algorithm.

\begin{tabular}{|c|c|c|c|c|c|c|}
\hline & Name of Site & $\begin{array}{c}\text { Number of } \\
\text { Houses }\end{array}$ & $\begin{array}{c}\text { Investment } \\
\text { Amount }(100 \mathrm{~m} .)\end{array}$ & Selection & $\begin{array}{c}\text { Number of } \\
\text { Selected Houses }\end{array}$ & $\begin{array}{c}\text { Investment } \\
\text { Amount }(100 \mathrm{~m} .)\end{array}$ \\
\hline \multirow{7}{*}{$\begin{array}{l}\text { Rental house } \\
(10)\end{array}$} & Gwanggyo A10 & 701 & 1196 & $x$ & - & - \\
\hline & Gwanggyo A16 & 224 & 374 & $x$ & - & - \\
\hline & Gwanggyo A19 & 1373 & 1212 & $\mathrm{O}$ & 1373 & 1212 \\
\hline & Gwanggyo A25 & 146 & 141 & $\mathrm{O}$ & 146 & 141 \\
\hline & Gwanggyo A26 & 1132 & 1859 & $\mathrm{O}$ & 1132 & 1859 \\
\hline & Gwanggyo A30 & 2091 & 1765 & $x$ & - & - \\
\hline & Gimpo Ab-2 & 559 & 1091 & $x$ & - & - \\
\hline \multirow{9}{*}{$\begin{array}{l}\text { Sales house } \\
\text { (10) }\end{array}$} & Gwanggyo-Edutown 13 15 & 1173 & 2225 & $\mathrm{O}$ & 1173 & 2225 \\
\hline & Gimpo-Hangang Ab-1 & 1167 & 2617 & $\mathrm{O}$ & 1167 & 2617 \\
\hline & Gimpo-Hangang Ab-7 & 1382 & 3028 & $\mathrm{O}$ & 1382 & 3028 \\
\hline & Wirye A2-11 & 1540 & 6758 & $x$ & - & - \\
\hline & Wirye A2-2 & 1413 & 4661 & $\mathrm{O}$ & 1413 & 4661 \\
\hline & Namyangju-Dasan B2 & 1186 & 2166 & $\mathrm{O}$ & 1186 & 2166 \\
\hline & Namyangju-Dasan B4 & 1615 & 2938 & $\mathrm{O}$ & 1615 & 2938 \\
\hline & Namyangju-Dasan S1 & 1685 & 2902 & $\mathrm{O}$ & 1685 & 2902 \\
\hline & Sub Total & 13,668 & 30,345 & 9 sites selected & 12,128 & 23,587 \\
\hline
\end{tabular}

The result of objective function (maximization of the number of suppled public rental houses) is 5773. 
Table 13 is the comparison of each method. The result from the genetic algorithm is superior to those from arbitrary selection \#1 and \#2. Also, the result of the branch the bound method is not better than that of arbitrary selection \#2.

Table 13. Comparison of the Supplied Number of Public Rental Houses.

\begin{tabular}{ccccc}
\hline Method & $\begin{array}{c}\text { Arbitrary } \\
\text { Selection \#1 }\end{array}$ & $\begin{array}{c}\text { Arbitrary } \\
\text { Selection \#2 }\end{array}$ & $\begin{array}{c}\text { Branch \& } \\
\text { Bound Method }\end{array}$ & $\begin{array}{c}\text { Genetic } \\
\text { Algorithm }\end{array}$ \\
\hline $\begin{array}{c}\text { Number of Public Rental } \\
\text { Houses }\end{array}$ & 2091 & 5297 & 5187 & 5773 \\
\hline
\end{tabular}

\section{Conclusions}

This study reviewed the optimal land development planning model and optimal urban regeneration planning model in South Korea. Then, it proposed an optimal project selection model to maximize the number of total supplied public rental houses with real-world project data.

There is a trade-off between the investment profit and investment amount needed to supply public rental houses. We applied a couple of optimization techniques such as the genetic algorithm and the branch and bound method to this combinatorial problem. The genetic algorithm obtained a superior result to those from arbitrary selections or the branch and bound method.

We think that this optimization model is a useful and practical planning tool for real estate investment projects while meeting various constraints including budget limitations, regional balance, and profit and welfare balance. Because real estate projects have no divisibility, we must decide whether or not to select any specific project. The genetic algorithm and branch and bound methods are useful tools for this kind of discrete optimization problems in real estate investment. Our optimization model may be applied to government-level infrastructure development plan in all over the country. With a limited budget, governments would select infrastructure (e.g., expressways, high-speed rail, facilities for disaster prevention, etc.) development projects which have different project effect, investment amount, and project location.

The model also can be applied to financial investment decisions with different returns of investment and risk among lots of bond, stock, commodities like gold or real estate. Investors would find an optimal investment portfolio obtaining objective profits under affordable risks with this model. The model saves considerable enumeration time with the trial and error method and proposes a reasonable basis for decisions.

Our research was limited by the amount of data available, thus we could not do a more detailed comparison between the various methods. If more data becomes available to us in the future, we can revisit this study and provide more precise comparisons between the different methods.

Author Contributions: J.H.P. proposed the idea, performed computation, and wrote the paper. J.-S.Y. supervised the research on real estate investment. Z.W.G. supervised the research on optimization formulation and algorithms. All authors have read and agreed to the published version of the manuscript.

Funding: This research was supported by the Energy Cloud R\&D Program through the National Research Foundation of Korea (NRF) funded by the Ministry of Science, ICT (2019M3F2A1073164).

Conflicts of Interest: The authors declare no conflict of interest.

\section{References}

1. MOLIT. Housing Welfare Roadmap, Ministry of Land; Infrastructure and Transport of Korea: Sejong, Korea, 2017.

2. OECD. Housing Dynamics in Korea-Building Inclusive and Smart Cities; OECD: Paris, France, 2018.

3. Li, X.; Parrott, L. An improved Genetic Algorithm for spatial optimization of multi-objective and multisite land use allocation. Comput. Environ. Urban Syst. 2016, 59, 184-194. [CrossRef]

4. Ng, S.T.; Skitmore, M.; Wong, K.F. Using genetic algorithms and linear regression analysis for private housing demand forecast. Build. Environ. 2008, 43, 1171-1184. 
5. Cao, K.; Huang, B.; Wang, S.; Lin, H. Sustainable land use optimization using Boundarybased Fast Genetic Algorithm. Comput. Environ. Urban Syst. 2012, 36, 257-269. [CrossRef]

6. Porta, J.; Parapar, J.; Doallo, R.; Rivera, F.F.; Sante, I.; Crecente, R. High performance genetic algorithm for land use planning. Comput. Environ. Urban Syst. 2013, 37, 45-58. [CrossRef]

7. Liu, Y.; Tang, W.; He, J.; Liu, Y.; Ai, T.; Liu, D. A landuse spatial optimization model based on genetic optimization and game theory. Comput. Environ. Urban Syst. 2015, 49, 1-14. [CrossRef]

8. Haque, A.; Asami, Y. Optimizing urban land use allocation for planners and real estate developers. Comput. Environ. Urban Syst. 2014, 46, 57-69. [CrossRef]

9. Ahn, J.J.; Byun, H.W.; Oh, K.J.; Kim, T.Y. Using ridge regression with genetic algorithm to enhance real estate appraisal forecasting. Expert Syst. Appl. 2012, 39, 8369-8739. [CrossRef]

10. Taber, J.T.; Balling, R.; Brown, M.R.; Day, K.; Meyer, G.A. Optimizing Transportation Infrastructure Planning with a Multiobjective Genetic Algorithm Model. J. Transp. Res. Board 1999, 1685, 51-56. [CrossRef]

11. Haque, A.; Asami, Y. Optimizing Urban Land-Use Allocation: Case Study of Dhanmondi Residential Area, Dhaka, Bangladesh. Environ. Plan. B Plan. Des. 2011, 38, 388-410. [CrossRef]

12. Cao, K.; Batty, M.; Huang, B.; Liu, Y.; Yu, L.; Chen, J. Spatial multi-objective land use optimization: Extensions to the non-dominated sorting genetic algorithm-II. Int. J. Geogr. Inf. Sci. 2011, 25, 1949-1969. [CrossRef]

13. Stewart, T.J.; Janssen, R.; Herwijnen, M.V. A genetic algorithm approach to multiobjective land use planning. Comput. Oper. Res. 2004, 31, 2293-2313. [CrossRef]

14. Zhang, H.H.; Zeng, Y.N.; Bian, L. Simulating Multi-Objective Spatial Optimization Allocation of Land Use Based on the Integration of Multi-Agent System and Genetic Algorithm. Int. J. Environ. Res. 2010, 4, 765-776.

15. Jin, Y.H.; Yu, J.S. Analysis of the Risk Factors of Block-unit Housing Rearrangement Project Using Fuzzy Multi-Criteria Decision-Making Method: Focusing on Incheon Metropolitan City Case. J. Korean Urban Manag. Assoc. 2019, 32, 87-112.

16. Chauhan, N.; Choi, B.-J. Denoising Approaches Using Fuzzy Logic and Convolutional Autoencoders for Human Brain MRI Image. Int. J. Fuzzy Log. Intell. Syst. 2019, 19, 135-139. [CrossRef]

17. Bae, S.; Yu, J. Estimation of the Apartment Housing Price Using the Machine Learning Methods: The Case of Gangnam-gu, Seoul. J. Korea Real Estate Anal. Assoc. 2018, 24, 69-85. [CrossRef]

18. Oh, S.-J.; Lim, C.-O.; Park, B.-C.; Lee, J.-C.; Shin, S.-C. Deep Neural Networks for Maximum Stress Prediction in Piping Design. Int. J. Fuzzy Log. Intell. Syst. 2019, 19, 140-146. [CrossRef]

19. Park, J.H.; Geem, Z.W.; Yu, J.S. The Optimal Investment Portfolio for Land Development Projects of Public Company. Korean Apprais. Rev. 2016, 26, 23-38.

20. Park, J.H.; Geem, Z.W.; Yu, J.S. The Optimal Project Combination for Urban Regeneration New Deal Projects. Korean Apprais. Rev. 2018, 28, 23-37.

21. Park, J.H.; Yu, J.S.; Geem, Z.W. Genetic Algorithm-based Optimal Investment Scheduling for Public Rental Housing Projects in South Korea. Int. J. Fuzzy Log. Intell. Syst. 2018, 18, 135-145. [CrossRef]

22. Lee, J.H.; Lim, S. An Analytic Hierarchy Process (AHP) Approach for Sustainable Assessment of Economy-Based and Community-Based Urban Regeneration: The Case of South Korea. Sustainability 2018, 10, 4456.

23. MOLIT. Urban Regeneration New Deal Project Seminar Booklet, Ministry of Land; Infrastructure and Transport of Korea: Sejong, Korea, 2017.

24. Ha, S.K. The Urban Poor, Rental Accommodations, and Housing Policy in Korea. Cities 2002, 19, $195-203$. [CrossRef]

(C) 2020 by the authors. Licensee MDPI, Basel, Switzerland. This article is an open access article distributed under the terms and conditions of the Creative Commons Attribution (CC BY) license (http://creativecommons.org/licenses/by/4.0/). 